\title{
Research on the Relationship among Phone Addiction, Social Anxiety and Loneliness in High School Students
}

\author{
Junlan Xu \\ International Department, the Second High School Attached to Beijing Normal University, Beijing, China \\ Email: Xujl1@outlook.com
}

How to cite this paper: Xu, J.L. (2017) Research on the Relationship among Phone Addiction, Social Anxiety and Loneliness in High School Students. Open Journal of Social Sciences, 5, 18-24.

https://doi.org/10.4236/jss.2017.56003

Received: February 28, 2017

Accepted: June 6, 2017

Published: June 9, 2017

\begin{abstract}
Phone addiction causes significant social and psychological damage to people who excessively use mobile phones. Rapid social rhythm, busy daily life, and complex interpersonal relationships make people, especially the student groups, increasingly dependent on mobile phones, and also gradually change their communication behaviors. This paper uses the way of psychological empirical study to investigate 220 students in a Beijing high school through the Mobile Phone Addiction Index, Liebowitz Social Anxiety Scale and UCLA Loneliness Scale. The results show that: (1) the ratio of phone addiction among phone users of high school students is about $17.95 \%$, and it varies significantly from different school department; (2) there is no correlation between phone addiction and social anxiety; (3) there is a higher sense of loneliness in classmates who have phone addiction. It can be seen that in modern society, mobile phone has become the main tool of social communication, and that it has little effect on social anxiety. Loneliness is one of the main reasons for phone addiction of high school students. Therefore, this paper suggests that in order to prevent high school students from excessively relying on the phone, the school need to take measures to limit the time of students using mobile phones; and strengthening the intimate relationship among school, family and students can help to reduce phone addiction by lowing the loneliness of students.
\end{abstract}

\section{Keywords}

High School Students, Phone Addiction, Social Anxiety, Loneliness

\section{Introduction}

On January $22^{\text {nd }}, 2017$, China Internet Network Information Center (CNNC) published the $39^{\text {th }}$ Statistical Report on Internet Development in China. UP to 
December 2016, the number of mobile netizens in China has reached 695 million, the growth rate for three consecutive years more than $10 \%$ [1]. The rapid development of cellphone media causes the expansion of the scale of phone addiction, which is shown especially by high school students.

There is no uniform definition of phone addiction, though. Referencing to the concept of Internet addiction, it can be defined as a new phenomenon that has both social and mental harm on people who overuse cellphones. Fast pace of social life and complicated interrelationships make people, especially the youth; tend to rely on cellphones, therefore gradually changing their communication behaviors.

Some studies have confirmed that mobile phone dependence has a certain impact on adolescents' interpersonal relationships. Ha et al. surveyed and assessed the psychological state of 595 adolescent cellphone users. The results indicate that teenagers who excessively use cellphones have trouble controlling their time of using cellphones, and are more likely to suffer from depression, anxiety disorder and self-esteem disturbance [2]. Sanchez-Martinez and Otero used questionnaires to investigate 1328 adolescents whose age range between 13 and 20, and found that depression, social isolation, drug and alcohol use, academic failure and other factors are associated with overuse of cellphones. These result simply that excessive phone use may relate to interpersonal problems [3]. Jin and Jack analyzed the relationship among mobile phone use, interpersonal motivation, face-to-face interaction and autism by questionnaire surveying 232 undergraduates who own cellphones. The results show that range of individual face-to-face communication is positively related to the motivation of interpersonal communication, the more face-to-face communication, the higher motivation of interpersonal interaction, and the more frequent use of mobile phones [4]. Han et al. believe that introverted teenagers are eager to associate with others, but they are afraid of opening their minds to others. Under this circumstance, mobile phone with its feature of hidden, virtual, relatively free becomes their topchoice to interact with people. However, the overuse of mobile phones is actually worsening their real-life relationships [5]. Zheng pointed out that the phone addiction has changed the way of people interaction and declined the initiative of communication [6].

This article discusses the relationship among the mobile phone addiction, social anxiety and loneliness of high school students, and provides suggestions for preventing and improving the situation of students' mobile phones addiction.

\section{Research Method}

\subsection{Research Subject}

Handing out 220 questionnaires to a high school in Beijing, the article recovers 195 effective questionnaires with the effectiveness of $88.67 \%$. The samples consist of 102 students from international department, and 93 students from normal department. There are 65 male students and 130 female students. 


\subsection{Research Tool}

1) The Mobile Phone Addiction Index MPAI

The article adopts The Mobile Phone Addiction Index developed by Louis Leung from Hong Kong University [7]. MPAI with fine validity and reliability is widely used by diagnosing the mobile phone addiction of teenagers and undergraduates. The scale consists of 17 questions, 4 dimensions which are out of control, withdrawal, avoidance and inefficiency. It employs 5-point scoring system. If answering in acknowledgment on 8 questions, subject can be considered as mobile phone addiction.

2) Liebowitz Social Anxiety Scale LSAS

The Liebowitz Social Anxiety Scale (LSAS) is a 24-item, self-rated scale used to assess how social phobia plays a part in people's life across a variety of situations by the degree people feel anxious and fearful [8]. Total scores of social anxiety consist of fear score (0: none, 1: mild, 2: moderate, 3 : severe) and avoidance score (0: never, 1: occasionally, 2: often, 3: severe). The higher the total scores, the more severe subjects have social anxiety and fear.

3) UCLA Loneliness Scale

The UCLA Loneliness Scale was developed to assess subjective feelings of loneliness or social isolation [9]. It includes 11 items worded in a negative or lonely direction and 9 items worded in a positive or non-lonely direction. It is described on a four point scale that ranged from "never' to "often." The higher the score, the more lonely people feel.

\section{Results and Discussion}

\subsection{Results of Mobile Phone Addiction}

Among 195 high school students, 35 students tend to have mobile phone dependence, contributing to the total number of $17.95 \%$, which is corresponding to the rate of Chinese undergraduate's mobile phone dependence (17.0\% - 26.1\%) [10].

With the abundance of mobile phone's functions, mobile phone dependence has shifted to high school teenager. Nowadays, there are more and more high school students tend to rely on mobile phones. The psychological reasons behind this situation are: (1) Conformist mentality. High school students are in immaturity. They are easy to conform to others and to chase for extravagant lifestyle in order to blend in with the crowd. (2) Psychological demands. Subjects study in a boarding school, which means that they can only meet their parents on weekends. Due to the heavy burden of study and the lack of collective activities and parental love, mobile phones become the important way to connect with society.

\subsection{Mobile Phone Addiction of High School Students in Different Sex, Major and Department}

The results show remarkable differences between international department and 
normal department $\left(\chi^{2}=4.523, p<0.05\right)$, and no differences in other classifications.

The research subjects are from the international department and the normal department. The international department is open to the usage of mobile phones and provides school $\mathrm{Wi}-\mathrm{Fi}$, while the normal department restricts students to use phones. The research shows that students in normal department are less likely to have mobile phone dependence. Closed school management shortens the time students spend on cell phones. There are $80.65 \%$ of the normal students spend time on mobile phones less than one hour, while only $32.35 \%$ of the international students do so.

High school students have not developed a mature mentality yet. They have weak self-control ability, especially when they come into contact with novelties. Once one student cannot resist the attractive of mobile phone, other students will be influenced. With time passing by, more and more students follow this flow of using mobile phones. If school does not adopt suitable method to manage students, this phenomenon will spread and become common. On the one hand, it can affect teenagers' study time and effectiveness. On the other hand, the information from internet without filter may influence students' mental health.

\subsection{The Relation between Mobile Phone Addiction and Social Anxiety}

Comparing the social anxiety scores between mobile phone dependence group and non-dependence group, the mobile phone dependence group has a relatively higher score on fear, avoidance and anxiety score. However, there are no remarkable differences between two groups.

Table 1. Phone addiction of high school students in different sex, major and department.

\begin{tabular}{ccccccc}
\hline & $\begin{array}{c}\text { International } \\
\text { Department }\end{array}$ & $\begin{array}{c}\text { General } \\
\text { Department }\end{array}$ & Male & Female & Art & Science \\
\hline $\begin{array}{c}\text { Dependence } \\
\text { Group } \\
\text { Independence } \\
\text { Group }\end{array}$ & 24 & 11 & 7 & 28 & 23 & 12 \\
$\chi^{2}$ & 78 & 82 & 58 & 102 & 76 & 84 \\
$p$ & 4.523 & & 3.413 & 3.812 \\
\hline
\end{tabular}

Table 2. Comparison of social anxiety scores of high school students $(M \pm S D)$.

\begin{tabular}{cccc}
\hline Phone Addiction & Fear Score & Avoidance Score & Anxiety Score \\
\hline Yes $(\mathrm{n}=35)$ & $20.69 \pm 12.53$ & $20.74 \pm 11.20$ & $41.43 \pm 22.02$ \\
No $(\mathrm{n}=160)$ & $17.68 \pm 11.55$ & $17.43 \pm 11.59$ & $35.10 \pm 21.15$ \\
$t$ & 1.279 & 1.444 & 0.139 \\
\hline$p$ & 0.203 & 0.150 & 0.487 \\
\hline
\end{tabular}


In the study of the relationship between mobile phone dependence and social anxiety, there is no prominent correlation. Nevertheless, according to other researches, total scores of mobile phone dependence and social anxiety have remarkable differences. The reason causing this divergence between researches may be the different research time. With the change of society, the impact of mobile phone dependence has changed as well.

Today's high school students have gotten in touch with cell phones 3 to 5 years ago. The subjects in this research have owned mobile phones for 4.01 years on average. Fast pace life restricts the time of face-to-face communication. In this situation, the gradually development of mobile communication technology paves a new way for people's demands on daily connection. As the younger generation, high school students accept novelties in a relatively rapid way than the older. Using mobile phone has become a normal way to communicate for teenagers, and they also have become the significant part of mobile media society. Consequently, there is no remarkable difference between high school student's mobile phone dependence and social anxiety.

\subsection{The Relationship between Phone Addiction and Loneliness}

Comparing the scores of mobile phone dependence group and non-dependency group, there is no prominent difference $(t=1.596, p>0.05)$. However, stratifying samples into several level, the consequence shows remarkable difference between two groups $\left(\chi^{2}=15.142, p<0.01\right)$.

This result proves that loneliness is one of mental reasons for students using cell phones. In these subjects, students who tend to rely on mobile phones show more remarkable loneliness. Cell phone media make people easy to get acquainted with new friends and join groups, communities that they are interested in. Nevertheless, due to the virtuality and anonymity of phone media, communicators can hardly establish trustful imitate relationship. As a result, the majority of alleged "friends" are actually strangers. People look forwards to get rid of loneliness, but they sink into collective loneliness anyway.

\section{Conclusions}

With the development of communication technology, mobile media has become the major communicative way for modern people. It is worth paying attention to high school students' mobile phone dependence phenomena.

Confronting to high school students' mobile phone dependence phenomena, schools should supervise and reasonably manage their use of cell phones. School

Table 3. Comparison of different degrees of loneliness.

\begin{tabular}{ccccccc}
\hline & Low & $\begin{array}{c}\text { General } \\
\text { Partial }\end{array}$ & Middle & General Bias & High & Total \\
\hline $\begin{array}{c}\text { Dependence } \\
\text { Group } \\
\begin{array}{c}\text { Independence } \\
\text { Group }\end{array}\end{array}$ & 0 & 2 & 5 & 5 & 23 & 35 \\
\hline
\end{tabular}


can neither implement over closed way to restrict the connection between students and society nor over open way. The former can digress students from world outside the school, therefore stimulating their rebel mentalities; the latter cannot control students' weak self-control ability, which makes students indulge in the Internet, distracting their concentration from study.

In interpersonal relationship part, family and school should aid students' mental health. Parents need to spare more time to communicate with their children, understanding teenagers' genuine thinking. School can add more activities that spur face-to-face communication between students. Through these activities, students can form an imitating interpersonal relation, which may solve their potential mental problems.

\section{Acknowledgements}

I would like to thank Prof. Chen Lihan of School of psychological and Cognitive Sciences, Peking University, who kindly gave me a hand when I was making the questionnaire and provided some suggestions during the writing of this paper.

\section{References}

[1] China Internet Network Information Center (CNNC) (2017) 39th Statistical Report on Internet Development in China. http://www.cnnic.cn/gywm/xwzx/rdxw/20172017/201701/t20170122 66448.htm

[2] Ha, J.H., Chin, B., Park, D.H., Ryu, S.H. and Yu, J. (2008) Characteristics of Excessive Cellular Phone Use in Korean Adolescents. Cyberpsychology \& Behavior, 11, 783-784. https://doi.org/10.1089/cpb.2008.0096

[3] Sanchez-Martinez, M. and Otero, A. (2009) Factors Associated with Cell Phone Use in Adolescents in the Community of Madrid (Spain). Cyberpsychology \& Behavior, 10, 424-435. https://doi.org/10.1089/cpb.2008.0164

[4] Jin, B. and Park, N. (2010) In-Person Contact Begets Calling and Texting: Interpersonal Motives for Cell Phone Use, Face-to-Face Interaction, and Loneliness. Cyberpsychology \& Behavior, 13, 611-618. https://doi.org/10.1089/cyber.2009.0314

[5] Han, D.L. and Qi, Z.F. (2005) Psychological Analysis of College Students' Mobile Phone Addiction. Contemporary Youth Studies, No. 12, 34-38.

[6] Zheng, Y.F. (2012) Analysis and Countermeasures of College Students' Mobile Addiction. Journal of Hubei Correspondence University, 4, 56-57.

[7] Leung, L. (2007) Linking Psychological Attributes to Addiction and Improper Use of the Mobile Phone among Adolescents in Hong Kong. Journal of Children and Media, 12-13.

[8] Liebowitz (2014) Test for Social Anxiety Disorder. Columbia University Medical Center, New York.

[9] Cutrona \& Carolyn (2013) UCLA Loneliness Scale. University of California, Los Angeles, USA.

[10] Huang, S.H. and Yu, D. (2010) A Survey of Mobile Phone Use and Dependence among College Students in Guangzhou. Health Science, 24, 3.

[11] Liu, X. and Liu, C.S. (2014) The Related Research in the Coping Style of Social Anxiety and the Tendency of Mobile Phone Dependence of Young People. Master's Thesis, Nanjing Normal University, Nanjing. 
[12] Ezoe, S., Toda, M., Yoshimura, K., et al. (2009) Relationships of Personality and Lifestyle with Mobile Phone Dependence among Female Nursing Students. Social Behavior \& Personality: an International Journal, 37, 231-238.

https://doi.org/10.2224/sbp.2009.37.2.231

Submit or recommend next manuscript to SCIRP and we will provide best service for you:

Accepting pre-submission inquiries through Email, Facebook, LinkedIn, Twitter, etc. A wide selection of journals (inclusive of 9 subjects, more than 200 journals)

Providing 24-hour high-quality service

User-friendly online submission system

Fair and swift peer-review system

Efficient typesetting and proofreading procedure

Display of the result of downloads and visits, as well as the number of cited articles

Maximum dissemination of your research work

Submit your manuscript at: http://papersubmission.scirp.org/

Or contact jss@scirp.org 